\title{
PENGARUH PENGGUNAAN SCIENTIFIC CREATIVE CRITICAL WORKSHEET (SCCW) PADA TOPIC ALAT OPTIK UNTUK MENINGKATKAN KEMAMPUAN PENALARAN ILMIAH SISWA KELAS X
}

\author{
Rahadiani Nurul Qonitaa), Saeful Karim ${ }^{\text {b) }}$ Selly Ferranie ${ }^{\text {c), }}$ \\ Duden Saepuzaman ${ }^{\text {d) }}$
} ${ }^{1}$ Departemen Pendidikan Fisika, Fakultas Pendidikan Matematika dan Ilmu Pengetahuan Alam, Universitas
Pendidikan Indonesia, Jl. Dr. Setiabudi No. 229, Bandung 40154, Indonesia.

Email: a) rnqonita@ student.upi.edu, b) saefulkarimsk@gmail.com, ${ }^{\text {c) }}$ feranie@upi.edu

\begin{abstract}
Abstrak
Tujuan dari penelitian ini yaitu untuk menyelidiki apakah ada pengaruh yang signifikan dari penggunaan Scientific Creative and Critical Worksheet (SCCW) dengan pembelajaran berbasis proyek dalam meningkatkan kemampuan penalaran ilmiah siswa pada materi alat-alat optik. 62 siswa kelas XI MIPA di Kota Cimahi ikut serta dalam penelitian ini. Penelitian ini menggunakan Scientific Creative and Critical Worksheet (SCCW) untuk melatihkan kemampuan penalaran ilmiah pada kelas eksperimen dan LKS biasa pada kelas kontrol. Perbedaan peningkatan ini dianalisis berdasarkan pola jawaban siswa dalam mengisi SCCW (kelas eksperimen) dan mereka yang mengisi lks biasa(kelas kontrol), hasil dari penelitian ini menunjukan bahwa ada perbedaan peningkatan pada hasil pretest-posttest kelas eksperimen yang menggunakan Scientific Creative Critical Worksheet (SCCW) dan hasil pretestposttest kelas kontrol yang menggunakan LKS biasa. Kelas eksperimen memiliki nilai N-Gain 0.41 (kategori sedang) dan kelas kontrol memiliki nilai N-Gain 0.34 (kategori sedang). Maka Scientific Creative Critical Worksheet efektif digunakan untuk melatihkan kemampuan berpikir kreatif ilmiah, kritis ilmiah dan kemampuan penalaran ilmiah siswa.
\end{abstract}

Kata-kata kunci: Scientific Creative Critical Worksheet, Project Based Learning, Optical Instrument, Scientific Reasoning

\begin{abstract}
The purpose of this research is to investigate whether there are some significant influence from application of Scientific Creative Critical Worksheet (SCCW) on project based learning for improving Scientific Reasoning Skill on optical instrument topic. The participant of this research were 62 students from eleventh grade science class in one of the private school in Cimahi. This research using Scientific Creative Critical Worksheet that contains problem to be solved to train Scientific Reasoning Skill for experimental class and ordinary worksheet for control class. The differences in this increase was analyzed based on the student answer on SCCW(experiment class) and ordinary worksheet(control class), the result of this research showed a significances between pretest-posttest experimental class that used Scientific Creative Critical Worksheet and control class that used ordinary worksheet. The experimental class has $\mathrm{N}-$ Gain value 0.41 which means it has high increase and the control class has $\mathrm{N}$ -
\end{abstract}


Gain value 0.34 which means it has low increase. Therefore, Scientific Creative Critical Worksheet is effective to incraese Scientific Reasoning Skill.

Keywords: Scientific Creative Critical Worksheet, Project Based Learning, Optical Instrument, Scientific Reasoning

\section{PENDAHULUAN}

Pesatnya perkembangan teknologi dan era digital yang terjadi di abad 21 memiliki berbagai dampak positif dalam kehidupan. Namun, kehidupan pada abad 21 pun akan semakin sulit antara lain meningkatnya persaingan antar manusia, untuk mempersiapkan orang-orang yang siap bersaing pada abad 21, banyak cara yang dapat dilakukan salah satunya melalui pendidikan. Sehingga penguatan karakter yang dilakukan disekolah harus dapat menumbuhkan karakter peserta didik yang mampu berpikir kritis, kreatif, mampu berkomunikasi, dan berkolaborasi sehingga peserta didik mampu bersaing di abad 21. Empat kompetensi yang harus dimiliki peserta didik pada abad 21 ini disebut dengan 4C, yaitu Critical Thingking dan Problem Solving (berpikir kritis dan menyelesaikan masalah), Creativity (kerativitas), Communication Skill (kemampuan berkomunikasi), dan Ability to Work Collaboratively (kemampuan untuk bekerja sama) [1].

Selain keterampilan abad 21 harus juga disertai dengan keterampilan penalaran ilmiah, Wenning dan Vierya (2015) [2] menjelaskan bahwa Keterampilan Penalaran Ilmiah adalah dimana proses dimana logika berpikir diterapkan pada proses sains, mencari penjelasan, merancang hipotesis, membuat prediksi, memecahkan masalah, menghasilkan percobaan, mengontrol variabel, menganalisis data, mengembangkan hukum empiris melalui pengembangan makna. Menurut Permendikbud No.22 tahun 2016 [3] bahwa untuk mencapai sasaran pembelajaran ranah keterampilan diperoleh melalui aktivitas mengamati, menanya, mencoba, menalar, menyaji, dan mencipta. Sehingga penalaran ilmiah penting bagi pendidikan agar siswa mampu bersaing di abad 21.

Untuk membantu dan mendukung peningkatan keterampilan abad 21 dibutuhkan perangkat pembelajaran yang dapat meningkatkan keterampilan abad 21 pada peserta didik terutama keterampilan berfikir kreatif dan keterampilan berpikir kritis. Dan keterampilan penalaran ilmiah. Penelitian sebelumnya mengungkapkan bahwa keterampilan penalaran imiah dapat ditingkatkan melalui eksperimen berbasis problem-solving [4]. Salah satu perangkat pembelajaran yang dapat memfasilitasi peserta didik untuk melatihkan keterampilan abad 21 adalah menggunakan worksheet. Worksheet memberikan kesempatan pada peserta didik untuk bekerja secara mandiri maupun berkelompok dan menumpahkan ide gagasan yang dimiliki peserta didik tersebut. Telah banyak dilakukan penelitian terkait pengembangan worksheet serta penggunaannya dalam pembelajaran fisika salah satunya Zulaiha (2016) [5]. Hasil penelitian menunjukkan worksheet yang dikembangkan layak untuk digunakan dalam pembelajaran fisika dan berhasil meningkatkan berpikir kritis.

Berdasarkam pemaparan diatas, dapat disimpulkan bahwa penelitian ini bertujuan untuk meningkatkan keterampilan penalaran ilmiah siswa melalui penggunaan SCCW (scientific creative and critical worksheet)

\section{METODOLOGI}

Metode yang digunakan dalam penelitian ini yaitu Quasi Experimental Design dengan desain penelitian Nonequivalent control group design. Dengan dua kelas, kelas eksperimen dan kelas kontrol. Kelas eksperimen merupakan kelas yang diberikan SCCW (Scientific Creative and Critical worksheet) dengan model pembelajaran berbasis proyek dan kelas kontrol merupakan kelas yang diberikan OW (Ordinari Worksheet) dengan model pembelajaran berbasis proyek. Kedua kelas diberikan tes sebelum dan setelah pembelajaran pada materi alat optik.

Populasi dalam penelitian ini adalah seluruh kelas XI MIPA pada tahun ajaran 2018/2019 disalah satu SMA Negeri di Kota Cimahi. Sampel yang digunakan yaitu dua kelas XI MIPA disekolah 
tersebut. Jumlah partisipan yang terlibat sebanyak 62 siswa dengan masing-masing 30 siswa pada kelas kontrol dan kelas eksperimen.

Aspek yang dinilai dalam penelitian ini merupakan keterampilan penalaran ilmiah siswa yang dihitung dengan menggunakan N-Gain. Kemudian setiap jawaban SCCW dan OW siswa dianalisis untuk mengetahui pengaruh pengggunaan terhadap peningkatan penalaran ilmiah.

Instrumen tes yang digunakan dalam penelitian ini berupa 20 butir soal pilihan ganda pada materi alat alat optik topik mikroskop dan teropong bulan. Terdapat 5 aspek keterampilan penalaran ilmiah yang digunakan pada penelitian ini mengacu pada framework Wenning dan Vierya 1) Describing relationships (Mendeskripsikan hubungan) 2) Determining if an answer to a problem or question is reasonable including size and/or units (Menentukan apakah jawaban dari masalah/pernyataan benar dan masuk akal termasuk ukuran dan besarnya) 3) Summarizing for the purpose of logically justifying a conclusion on the basis of empirical evidence (Meringkas secara logis dengan bukti empiris untuk membenarkan suatu kesimpulan) 4) Using data and math in the solution of real-world problems (Menggunakan data dan matematika dalam memecahkan permasalahan di dunia nyata) 5) Using proportional reasoning to make predictions (Menggunakan penalaran yang proporsional untuk membuat prediksi). Lima aspek yang dipilih tersebar dalam 20 butir soal pilihan ganda yang disajikan TABEL 1.

TABEL 1. Sebaran Aspek Keterampilan Penalaran Ilmiah dalam Instrumen

\begin{tabular}{ll}
\hline Aspek Keterampilan Penalaran Ilmiah & Nomor Soal \\
\hline 1) Describing relationships & $7,17,18$ \\
2) Determining if an answer to a problem or question is & 1,9 \\
reasonable including size and/or units & \\
3) Summarizing for the purpose of logically justifying a & 15 \\
conclusion on the basis of empirical evidence & $3,4,5,6,8,12,13,14$, \\
4) Using data and math in the solution of real-world & 19,20 \\
problems & $2,10,11,16$ \\
& \\
5) Using proportional reasoning to make predictions &
\end{tabular}

\section{HASIL DAN PEMBAHASAN}

Dari perolehan skor hasil pretest-posttest yang didapatkan kelas kontrol dan kelas eksperimen, lalu dihitung dengan menggunakan rumusan N-Gain didapatkan hasil seperti pada TABEL 2

TABEL 2. Rekapitulasi Peningkatan Hasil Tes Keterampilan Penalaran Ilmiah

\begin{tabular}{lllll}
\hline & \multicolumn{2}{l}{ Kelas Kontrol (OW) } & $\begin{array}{c}\text { Kelas } \\
(\text { SCCW })\end{array}$ & Eksperimen \\
\cline { 2 - 5 } & Pretest & posttes & Pretest & posttest \\
\hline Skor maksimal & 20 & 20 & 20 & 20 \\
Skor rata-rata & 4,09 & 9,58 & 4,90 & 11,16 \\
Nilai N-Gain & 0,34 & & 0,41 & \\
Kategori & Sedang & & Sedang & \\
\hline
\end{tabular}

Dari TABEL 2 diperoleh bahwa keterampilan penalaran ilmiah siswa lebih tinggi menggunakan SCCW dibandingkan kelas yang menggunakan OW dalam pembelajaran berbasis proyek. Perolehan $\mathrm{N}$-Gain keterampilan penalaran ilmiah siswa dengan menggunakan SCCW sebesar 0,41 (sedang) lebih tinggi dibandingkan dengan kelas yang menggunakan OW sebesar 0,34 (sedang). Hal ini dikarenakan SCCW bukan hanya melatihkan keterampilan berpikir kreatif dan kritis ilmiah tapi juga 
dapat melatihkan keterampilan penalaran ilmiah. Hubungan aspek keterampilan penalaran ilmiah, pertanyaan SCCW dengan pertanyaan OW disajikan dalam TABEL 3

TABEL 3. Hubungan aspek keterampilan penalaran ilmiah, pertanyaan OW, dan pertanyaan SCCW

\begin{tabular}{lcccc}
\hline $\begin{array}{c}\text { Aspek Keterampilan } \\
\text { Penalaran Ilmiah }\end{array}$ & $\begin{array}{c}\text { Pertanyaan } \\
\text { (Ordinary Worksheet) }\end{array}$ & OW & $\begin{array}{c}\text { Pertanyaan } \\
\text { (Scientific Creatif } \\
\text { Critical Worksheet) }\end{array}$ \\
\hline 1)Describing relationships & Faktor apa saja yang & Apakah dari alat yang \\
& akan mempengaruhi alat dibuat ada variabel yang \\
& yang kalian buat? & $\begin{array}{l}\text { saling mempengaruhi? Jika } \\
\text { ada, sebutkan hubungan }\end{array}$ \\
& & $\begin{array}{l}\text { antar variabel tersebut? }\end{array}$
\end{tabular}

2)Determining if an Dari alat yang kalian Teman A : untuk answer to a problem or buat,apakah ancangan membuat mikroskop dan question is reasonable tersebut dapat membantu dapat membuat benda kecil including size and/or Bastian? Jika tidak, lakukan terlihat lebih jelas digunakan units analisis lensa cembung sebagai lensa objektif dan lensa cembung sebagai lensa okuler

Teman B : untuk membuat mikroskop dan dapat membuat benda kecil terlihat lebih jelas digunakan lensa cembung sebagai lensa okuler dan lensa cekung sebagai lensa objektif

Menurut kalian pendapat manakah yang paling tepat? Apakah pendapat tersebut sama dengan ide rancangan teropong yang kalian buat?

3)Summarizing for the purpose of logically justifying a conclusion on the basis of empirical evidence

$\begin{array}{lrl}\text { Berdasarkan } & \text { kegiatan } & \text { Apakah rancangan alat } \\ \text { diatas, anda } & \text { dapat } & \text { yang kalian buat dapat } \\ \text { menyimpulkan.... } & & \text { menghasilkan kesimpulan } \\ & \text { yang benar? Dan } \\ & \text { membuktikan pendapat yang } \\ & \text { telah kalian kemukakan } \\ & \text { sebelumnya? Jelaskan? }\end{array}$




\section{4)Using data and math in the solution of real- world problems}

Berdasarkan analisis kalian, buatlah langkah kerja untuk membuat mikroskop tersebut!

\section{5)Using proportional reasoning to make predictions}

Buatlah ide rancangan untuk membuat mikroskop yang dibutuhkan Bastian!
1) 2 lensa cembung dengan panjang fokus yang berbeda

2) 1 lensa cekung

3) Tabung

4) Alat dan bahan yang ada di sekitar kalian

Dari alat dan bahan yang tersedia mana yang akan kalian gunakan untuk membantu bastian? Jika alat dan bahan tidak tersedia dalam daftar tuliskan alat dan bahan tersebut?

Bagaimana langkah kerja dalam pembuatan mikroskop sederhana yang dilakukan oleh kelompok kalian?

Rancanglah sebanyak mungkin alat sederhana . Yang dapat membuat Bastian melihat benda yang ditemukannya . Gunakan alat dan bahan yang diperlukan untuk membuat alat sederhana . (Semakin banyak ide rancangan, semakin banyak nilai plus)

Berdasarkan TABEL 3 dapat dilihat bahwa adanya perbedaan pertanyaan yang diberikan kepada kelas kontrol dan kelas eksperimen. Pertanyaan-pertanyaan yang diberikan pada kelas kontrol berupa pertanyaan-pertanyaan singkat yang biasa digunakan dalam LKS pada umunya sedangkan pertanyaan pada SCCW yang diberikan pada kelas eksperimen adalah pertanyaan-pertanyaan yang disusun berdasarkan framework SCCM dan ACTA, sehingga keterampilan penalaran ilmiah siswa lebih terlatihkan pada saat siswa menggunakan SCCW dibandingkan dengan menggunakan OW. Berikut disajikan GAMBAR 1 dan 2 mengenai perbandingan jawaban kelas kontrol menggunakan OW dan kelas eksperimen menggunakan SCCW

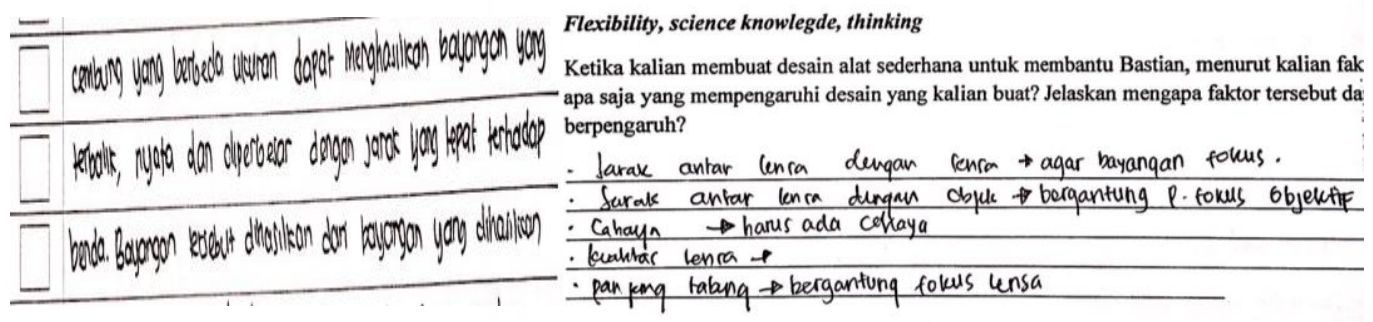


GAMBAR 1. Jawaban siswa kelas kontrol pada OW dan kelas eksperimen pada SCCW aspek Describing Relationship

Dari gambar jawaban siswa pada kelas kontrol (a) dan eksperimen (b) diatas dapat dilihat perbedaan bahwa pada kelas kontrol hanya mampu menuliskan satu hubungan antar variabel yang mempengaruhi ide rancangan yang mereka buat, sedangkan pada kelas eksperimen siswa mampu menyebutkan lebih dari tiga hubungan variabel dan faktor yang mempengaruhi dalam membuat ide rancangan beserta alasan-alasannya. Hal ini membuktikan bahwa SCCW dapat melatihkan keterampilan penalaran ilmiah siswa untuk mendeskripsikan hubungan antar variabel dan faktorfaktor yang mempengaruhi suatu alat.

\section{SIMPULAN}

Penggunaan Lembar Kerja Kreatif dan Kritis Ilmiah (LK3I) lebih meningkatkan keterampilan penalaran ilmiah siswa dibandingkan dengan menggunakan Lembar Kerja Siswa (LKS). Peningkatan kerampilan penalaran ilmiah pada kelas eksperimen dan kontrol berada dalam kategori sedang namun kelas eksperimen memiliki nilai $\mathrm{N}$-Gain lebih besar dibandingkan dengan kelas kontrrol.

\section{REFERENSI}

[1] Kementerian Pendidikan dan Kebudayaan. Pendidikan Karakter Dorong Tumbuhnya Kompetensi Siswa Abad 21. Jakarta. 2017

[2] Hanson, S. "The Assessment Of Scientific Reasoning Skills Of High School Science Students: A Standardized Assessment Instrument". Thesis and Disserrtations. Illinois State University. Paper 506, 2016

[3] Peraturan Menteri Pendidikan dan Kebudayaan Republik Indonesia No. 22 Standar Proses Pendidikan Dasar dan Menengah. Pemerintah Republik Indonesia. 2016.

[4] Nugraha, M. G., Kirana, K. H., Utari, S., Kurniasih, N., Nurdini, N., \& Sholihat, F. N. "Problem Solving-Based Experiment untuk Meningkatkan Keterampilan Penalaran Ilmiah Mahasiswa Fisika”. Jurnal Penelitian \& Pengembangan Pendidikan Fisika, 3(2), pp.137 144, 2017. https://doi.org/10.21009/1.03203

[5] Zulaiha, F. "Pengembangan Worksheet dan Problemsheet Berorientasi Keterampilan Berpikir Kritis Menggunakan Multimodus Representasi untuk Pembelajaran Fisika di SMA/MA". Tesis UPI, 2016. 